\title{
Panen dan Pascapanen Kelor (Moringa oleifera Lam.) Organik di Kebun Organik Kelorina, Blora, Jawa Tengah
}

\section{Harvest and Post-harvest Moringa (Moringa oleifera Lam.) Organic in Kunduran Plantation, Blora, Central Java}

\author{
Chandi Tri Akbar, Ketty Suketi*, dan Juang Gema Kartika \\ Departemen Agronomi dan Hortikultura, Fakultas Pertanian, Institut Pertanian Bogor \\ (Bogor Agricultural University), Jl. Meranti, Kampus IPB Darmaga, Bogor 16680, Indonesia \\ Telp. \& Faks.62-251-8629353 e-mail agrohort@apps.ipb.ac.id \\ *Penulis Korespondensi : kettysuketi@yahoo.com
}

Disetujui : 21 Mei 2018 / Published Online September 2019

\begin{abstract}
Moringa research in Blora aims to study the effect of different leaf harvesting techniques and to study the best technique in postharvest and processing to good quality of moringa. Sustain supervision and sosialization about standard operational should be given to the farmer for guaranteed quality of main ingredient. The criteria of moringa leaves that can be harvested are: has petiole which is $45-90^{\circ}$ angle, the bud has appeared at it armpit and the leaf has a darker green colour. The harvest of moringa with branch pruning more suitable to produce feeds. The harvest of moringa by leaf picking technique is more suitable for food production. Drying is the most important key in moringa leaf production. The drying room temperature is maintained at 30-35 ${ }^{\circ} \mathrm{C}$ and moisture is made up to $46 \% \mathrm{RH}$ for two days. Pre drying treatment or without drying doesn't effect percentage of moring a leaf rendement.
\end{abstract}

Keywords: branch pruning, drying, leaf picking, quality of production

\begin{abstract}
ABSTRAK
Penelitian kelor di Blora ini bertujuan untuk mempelajari pengaruh perbedaan teknik panen terhadap produksi daun dan mempelajari metode pascapanen dan pengolahan kelor yang tepat untuk menghasilkan kelor berkualitas. Pengawasan dan sosialisasi yang berkelanjutan terkait standar operasional prosedur penting dilakukan kepada petani mitra untuk menjamin kualitas bahan baku yang tetap. Kriteria daun kelor yang dapat dipanen yaitu tangkai daun sudah memiliki sudut tangkai daun antara $45^{\circ}-90^{\circ}$, sudah muncul sedikit bakal daun di ketiak daunnya dan daun berwarna hijau tua. Panen kelor dengan teknik pangkas cabang lebih cocok digunakan untuk produksi pakan ternak. Kelor yang dipanen dengan teknik petik daun lebih cocok digunakan untuk tujuan produksi pangan. Pengeringan merupakan kunci terpenting dalam produksi kelor. Suhu ruang pengering dipertahankan 30-35 ${ }^{\circ} \mathrm{C}$ dengan kelembapan dibuat hingga $46 \% \mathrm{RH}$ selama dua hari. Perlakuan pra pengeringan dan tanpa pra pengeringan tidak mempengaruhi persentase rendemen daun kelor.
\end{abstract}

Kata kunci: kualitas produksi, pangkas cabang, pengeringan, petik daun 


\section{PENDAHULUAN}

Indonesia pada tahun 2016 memiliki jumlah penduduk sebesar 258704986 jiwa. Menurut data penimbangan dan status gizi (PSG) balita tahun 2016 dengan indeks berat badan per umur $(\mathrm{BB} / \mathrm{U})$ pada balita 0-59 bulan, terdapat persentase gizi buruk sebesar $3.4 \%$, gizi kurang sebesar $14.4 \%$ dan gizi lebih sebesar $1.5 \%$. Angka tersebut tidak jauh berbeda dengan hasil PSG 2015, yaitu gizi buruk sebesar $3.9 \%$, gizi kurang sebesar $14.9 \%$ dan gizi lebih sebesar 1.6\%. Provinsi dengan gizi buruk dan kurang tertinggi tahun 2016 adalah Nusa Tenggara Timur (28.2\%) dan terendah Sulawesi Utara (7.2\%) (Sutarjo dan Budijanto, 2017). Kelor merupakan salah satu solusi untuk mengatasi permasalahan gizi buruk yang ada di Indonesia.

Kelor merupakan tanaman yang sering disebut "The Miracle Tree" karena memiliki potensi untuk menyelesaikan permasalahan kekurangan gizi, serta mencegah dan mengobati berbagai penyakit. Kelor mengandung 539 senyawa yang dikenal dalam pengobatan tradisional Afrika (Krisnadi, 2015). Pohon kelor telah digunakan untuk memerangi malnutrisi, terutama di kalangan bayi dan ibu-ibu menyusui. Satu sendok makan $(8 \mathrm{~g})$ bubuk daun kelor akan memenuhi sekitar $14 \%$ protein, $40 \%$ kalsium, $23 \%$ zat besi dan hampir semua kebutuhan vitamin A untuk anak usia 1-3 tahun (Mishra et al., 2012). Daun kelor merupakan sumber nutrisi dan energi alami yang baik. Berdasarkan hasil analisis proksimat mengungkapkan, bahwa daun kelor memiliki nilai gizi yang tinggi seperti phytochemical, vitamin, mineral, protein dan asam amino. Daun kelor dapat digunakan sebagai agen antioksidan dan antimikroba alami yang dapat diaplikasikan dalam farmasi dan makanan (Sohaimy et al., 2015). Teknik dehidrasi merupakan cara untuk mengkonsentrasikan nutrisi dan mengawetkan pada sayuran daun. Daun kelor juga tersedia banyak dan murah, serta dapat berfungsi sebagai sumber nutrisi dan dapat dikembangkan di negara-negara yang memerangi defisiensi mikro nutrisi (Joshi dan Mehta, 2010).

Masyarakat Indonesia masih banyak yang belum mengetahui bagaimana pemanfaatan kelor, umumnya hanya dikenal sebagai salah satu menu sayuran (Aminah et al., 2015). Keterbatasan pengetahuan masyarakat mengenai manfaat dan cara budidaya kelor, menyebabkan aksi konservasi yang dilakukan masyarakat terhadap kelor masih rendah (Desiawati, 2013). Produksi tanaman kelor dipengaruhi oleh pemangkasan, karena dengan pemangkasan akan mendorong pertumbuhan cabang kelor (Holst, 2000).
Pengetahuan terkait teknik budidaya kelor yang tepat dibutuhkan, sehingga kelor berproduksi optimal. Metode pascapanen dan pengolahan kelor juga penting dipelajari untuk menghasilkan produk yang berkualitas.

Potensi kelor yang tinggi dan belum banyak dibudidayakan di Indonesia, maka penulis tertarik untuk melakukan penelitian di Kebun Organik Kelorina yang terdapat di Kabupaten Blora. Kebun Organik Kelorina merupakan satu-satunya pusat pelatihan kelor yang ada di Indonesia dan pelopor revolusi nutrisi dengan gerakan kelor. Kelor dikembangkan untuk meningkatkan popularitas serta pemenuhan kebutuhan pasar di masa yang akan datang. Kegiatan penelitian bertujuan mempelajari pengaruh perbedaan teknik panen terhadap produksi daun dan mempelajari metode pascapanen dan pengolahan kelor yang tepat untuk menghasilkan kelor yang berkualitas.

\section{BAHAN DAN METODE}

Pengamatan penelitian dilakukan di dua tempat, yaitu pengamatan budidaya di kebun kelor Blora milik petani mitra dan pengamatan pengolahan di unit pengolahan kelorina, Kebun Organik Kelorina, Blora, Jawa Tengah. Kegiatan ini berlangsung selama empat bulan dimulai pada tanggal 8 Februari hingga 5 Juni 2018. Data yang dikumpulkan berupa data primer dan data sekunder. Data primer diperoleh dari hasil kegiatan wawancara dan diskusi dengan direktur, kepala produksi, kepala pengolahan dan pemasaran, karyawan, serta hasil pengamatan langsung di lapang. Pengamatan dilakukan pada sepuluh tanaman contoh di empat blok lahan produksi. Aspek yang diamati adalah sebagai berikut.

\section{Pengaruh Perbedaan Teknik Panen Terhadap Produksi Daun Kelor}

Percobaan dilakukan dengan satu faktor, yaitu teknik panen. Terdapat dua taraf terdiri dari teknik panen petik daun dan panen pangkas cabang. Perlakuan dilakukan pada sepuluh tanaman yang dipanen dengan teknik petik daun dan sepuluh tanaman yang dipanen dengan teknik pangkas cabang yang berada di blok yang sama. Panen dilakukan selama tiga periode, satu periode panen adalah 35 hari. Pengamatan dilakukan setiap minggu untuk teknik panen petik daun dan 35 hari sekali untuk teknik panen pangkas cabang. Hasil pengamatan dengan teknik panen petik daun dijumlahkan dari minggu pertama hingga minggu ke lima pada setiap periode panen, kemudian dibandingkan dengan hasil pengamatan dengan teknik panen pangkas cabang. Pemanenan 
dilakukan pada interval lima minggu dengan cara memotong cabang yang terbentuk sepanjang $5 \mathrm{~cm}$ dari pangkal cabang menggunakan gunting stek yang mengacu pada Mitariastini (2016) dan pemanenan dengan interval satu minggu dengan cara petik daun mengacu pada standar operasional perusahaan. Pengamatan meliputi, jumlah daun panenan, jumlah daun tripinnate saat panen. Jumlah cabang panenan, cabang yang dipanen dihitung jumlahnya per tanaman. Bobot basah brangkasan $(\mathrm{g})$, bobot semua bagian tanaman yang dipangkas saat panen. Bobot basah anak daun $(\mathrm{g})$, anak daun yang ditimbang merupakan helaian anak daun tanpa tangkai daun maupun tangkai anak daun dan masih berwarna hijau (daun yang berwarna kuning tidak dihitung).

\section{Pengaruh Perbedaan Perlakuan Pra Pengeringan Terhadap Rendemen Daun Kelor Kering}

Percobaan dilakukan dengan satu faktor, yaitu pra pengeringan. Taraf percobaan ada dua, yaitu daun yang masuk pengering dengan perlakuan pra pengeringan dan tanpa pra pengeringan. Pra pengeringan adalah daun dimasukan ruang pengering dua jam lebih awal serta ruangan diberi perlakuan dengan menyalakan kipas angin dan exhaust fan. Proses pengeringan dimulai bersamaan dengan periode 44 jam. Percobaan diulang tiga kali mengikuti jadwal pengeringan yang ada di perusahaan. Percobaan dilakukan pada satu rak yang berkapasitas $2 \mathrm{~kg}$ untuk masing-masing perlakuan. Rak pengering yang dipilih adalah rak yang berada di bagian tengah ruangan untuk meminimalkan pengaruh posisi lampu sorot. Daun dapat kering setelah dua hari di dalam ruang pengering dan dapat dikemas setelah kadar air daun di bawah 5\% atau hancur ketika diremas. Pengamatan meliputi bobot akhir daun yang sudah dikeringkan $(\mathrm{g})$, rendemen daun, yaitu membagi bobot kering daun (g) dengan bobot basah daun (g) dan kehilangan hasil, yaitu bobot daun yang terjatuh di ruang pengering atau daun yang tidak ikut dikemas $(\mathrm{g})$

Data sekunder didapat dari arsip dan studi literatur perusahaan berupa peta lokasi wilayah, luas areal, kondisi tanah dan iklim, topografi lahan, kondisi populasi dan produksi tanaman, data curah hujan 5-10 tahun terakhir, struktur organisasi dan ketenagakerjaan, serta sarana dan prasarana kebun. Data yang telah dikumpulkan dianalisis secara deskriptif maupun kuantitatif. Data primer dan sekunder yang bersifat kuantitatif (numeric) seperti bobot anak daun tanaman kelor dan hasil produksi dianalisis dengan menggunakan analisis kuantitatif menggunakan rata-rata dan standar deviasi, sedangkan data yang bersifat kualitatif dianalisis dengan menggunakan analisis deskriptif. Data hasil pengamatan pengaruh tinggi pangkasan terhadap produksi kelor diuji menggunakan uji Independent T-test.

Kebun kelor Blora terletak di Desa Ngawenombo, Kecamatan Kunduran, Kabupaten Blora, Jawa tengah. Secara geografis terletak antara $06^{\circ} 58^{\prime} 48.15^{\prime \prime}-07^{\circ} 09^{\prime} 2.76^{\prime \prime}$ LS dan $111^{\circ} 11^{\prime} 42.47^{\prime \prime}-111^{\circ} 18^{\prime} 59.25^{\prime \prime}$ BT. Kebun kelor Blora mulai dibudidayakan tanggal 15 Agustus 2015. Luas areal kebun petani mitra yang ada di Blora adalah 3 ha. Pabrik atau unit pengolahan kelorina Kebun Organik Kelorina berada di jalan raya kunduran yang berfungsi sebagai tempat pengolahan produk olahan kelor. Puri Kelorina berjarak $500 \mathrm{~m}$ dari kebun yang berfungsi sebagai tempat pelatihan kelor. Berdasarkan penelitian Martha et al. (2016), Kabupaten Blora memiliki curah hujan rata-rata $1496 \mathrm{~mm}$ tahun $^{-1}$, kelembaban udara rata-rata $34-44 \%$, suhu rata-rata 36-41 ${ }^{\circ} \mathrm{C}$ dan memiliki intensitas cahaya 7,633 lux. Jenis tanah di Blora merupakan tanah entisol (silt). Jenis tanah entisol tergolong tanah yang biasanya kurang subur.

Kelor ditanam secara organik di lahan yang sebelumnya tidak pernah digunakan untuk budidaya anorganik. Bibit untuk pertanaman menggunakan aksesi yang berasal dari NTT. Pengelolaan kebun kelor Blora milik petani mitra mengikuti standar operasional prosedur, dimulai dari pemilihan lokasi, pengolahan tanah minimal, pemupukan dengan pupuk organik yang dibuat sendiri, pemilihan benih, pola tanam dan pemeliharaan yang bebas dari residu kimia. Kebutuhan daun untuk pemenuhan produksi dipenuhi dari kebun kelor organik yang ada di Blora dan Madura. Sedangkan biji di produksi di kebun organik kelor yang ada di NTT dan Madura Kebun organik kelor yang berada di Madura dan NTT merupakan petani mitra dengan standar operasional produksi yang sama. Kebun Organik Kelorina menerima bahan baku berupa daun kering, serbuk kasar atau biji dari petani mitra, sedangkan Kebun Organik Kelorina fokus dalam pengolahannya. Produksi kebun kelor Blora dibagi menjadi empat tujuan, yaitu blok 1-4 dengan luas 2.4 ha untuk produksi daun kering dan serbuk halus sedangkan blok 5 dengan luas lahan 0.6 ha untuk bahan pakan ternak dan pembuatan pupuk. Produksi kebun kelor Blora dapat di lihat pada Tabel 1. Produksi basah, serbuk kasar dan daun kering memiliki rata-rata $1,962.8 \mathrm{~kg}, 395.6 \mathrm{~kg}$ dan $49.28 \mathrm{~kg}$ per bulannya. Produksi mengalami penurunan pada bulan Januari hingga $186 \mathrm{~kg}$ karena serangan hama ulat. Serangan hama ulat yang hebat diatasi dengan 
Tabel 1. Produksi pertanaman kelor di kebun kelor Blora dengan luas 2.4 ha

\begin{tabular}{lccccc}
\hline Bulan & Bobot Basah $(\mathrm{kg})$ Bobot Kering $(\mathrm{kg})$ & $\begin{array}{c}\text { Rendemen } \\
(\%)\end{array}$ & $\begin{array}{c}\text { Bobot Serbuk Kasar } \\
(\mathrm{kg})\end{array}$ & $\begin{array}{c}\text { Bobot Daun Kering } \\
(\mathrm{kg})\end{array}$ \\
\hline November 2017 & 2835.00 & 607.80 & 21.00 & 577.80 & 30.00 \\
Desember 2017 & 2276.00 & 582.10 & 24.00 & 475.40 & 106.70 \\
Januari 2018 & 186.00 & 17.70 & 23.00 & 15.30 & 2.40 \\
Februari 2018 & 2064.00 & 464.50 & 23.00 & 378.40 & 86.10 \\
Maret 2018 & 2453.00 & 552.10 & 23.00 & 530.90 & 21.20 \\
Rata-rata & 1962.80 & 444.80 & 22.80 & 395.60 & 49.28 \\
\hline
\end{tabular}

Sumber: Data Kebun Organik Kelorina (2018).

memangkas seluruh pertanaman kelor. Tingginya serangan ulat diduga akibat kondisi kekeringan yang cukup panjang.

Kapasitas mesin pengering hanya dapat menampung $200 \mathrm{~kg}$ daun yang sudah dilorot per dua hari pengeringan, menyebabkan masih banyak daun yang telat dipanen. Berdasarkan hasil pengamatan, kelor menghasilkan rata-rata $61.4 \mathrm{~g}$ daun yang sudah dilorot per tanamannya, sehingga dibutuhkan 3,258 tanaman untuk memenuhi kapasitas ruang pengering. Jarak tanam yang digunakan adalah $1 \mathrm{~m} \times 1 \mathrm{~m}$, sehingga terdapat 10000 tanaman kelor per hektarnya. Kelor dapat memproduksi $614 \mathrm{~kg}$ daun yang sudah dilorot dalam satu kali panen per hektarnya. Kapasitas ruang pengering $200 \mathrm{~kg}$ dan dengan asumsi pengeringan dilakukan satu minggu tiga kali, maka perbandingan jumlah luasan kebun yang dimiliki dengan kapasitas ruang pengering kurang efisien. Produksi rata-rata daun yang sudah dilorot perbulannya adalah 1 $962 \mathrm{~kg}$ (Tabel 1). Diperlukan tambahan kapasitas ruang pengering sehingga pemanfaatan hasil panen dapat berjalan dengan baik.

\section{HASIL DAN PEMBAHASAN}

Observasi penelitian dilakukan bersama petani mitra, yaitu kegiatan budidaya, meliputi: persiapan lahan, penanaman, pemeliharaan, panen dan pascapanen. Sedangkan kegiatan yang dilakukan bersama Kebun Organik Kelorina, yaitu kegiatan pengolahan.

\section{Aspek Teknis}

Lahan dipersiapkan dengan cara dibuat guludan dengan lubang tanam yang dibuat dengan ukuran lebar $30 \mathrm{~cm}$ dengan kedalaman $20 \mathrm{~cm}$. Jarak tanam yang digunakan $1 \mathrm{~m} \times 1 \mathrm{~m}$. Jarak tanam yang renggang digunakan untuk memudahkan dalam perawatan dan pemanenan. Lubang-lubang tersebut kemudian diisi pupuk bokashi sebanyak $1.5 \mathrm{~kg}$ per lubang. Kelor dapat ditanam dengan menggunakan biji dan stek batang.
Pemupukan pertama dilakukan selama persiapan lahan dengan pupuk kandang 10-15 ton $\mathrm{ha}^{-1}$. Pemupukan rutin dilakukan minimal tiga bulan sekali dengan bokashi dengan jumlah 500 $\mathrm{kg} / \mathrm{ha}$. Sebelum diberikan bokashi, tanah dibuat alur pupuk dan disiram dengan asam humat dengan dosis $200 \mathrm{ml} \mathrm{ha}^{-1}$. Bokashi terbuat dari campuran kotoran sapi, kotoran walet, daun trembesi, air kelapa, bonggol pisang dan urine sapi. Pemupukan juga dilakukan setelah panen dilakukan atau satu minggu sekali dengan menggunakan pupuk asam amino dan pupuk daun. Aplikasi asam amino dan pupuk daun dengan dosis masing-masing $200 \mathrm{ml} \mathrm{ha}^{-1}$. Asam amino terbuat dari daun kelor, glisina dan metionina dari kedelai. Asam amino berfungsi untuk mempercepat waktu panen sehingga dapat dipanen satu minggu sekali. Pupuk daun terbuat dari campuran pupuk organik cair, bio urine dan unsur N, P dan K organik. Irigasi diberikan secara teratur selama tiga bulan pertama setelah tanam. Irigasi juga diperlukan untuk menghasilkan daun sepanjang tahun, termasuk pada musim kemarau. Sistem irigasi yang digunakan adalah selang air dan sprinkler. Irigasi hanya mengandalkan air hujan pada saat musim hujan. Penyiangan untuk pertanaman kelor yang intensif dilakukan empat kali dalam setahun dengan frekuensi yang lebih tinggi saat musim hujan. Hama yang umum terdapat di lapangan adalah ulat. Larva dari ngengat juga banyak menyerang pertanaman pada malam hari. Solusi terbaik dalam mengatasi serangan hama yang hebat adalah memotong kembali batang pohon. Penyakit yang paling banyak menyerang tanaman kelor di lapangan adalah ganoderma juga banyak menyerang pertanaman kelor, gejala awalnya adalah daun akan menguning, batang membusuk dan akhirnya tanaman mati. Ganoderma dapat menyebar ke pertanaman lain. Pengendalian dilakukan dengan mencabut tanaman kelor dan mencangkul bekas pertanaman yang terserang ganoderma, tanah disemprot dengan tricoderma dengan dosis 200 $\mathrm{ml} /$ ha dan lubang dibiarkan 2-3 hari terpapar sinar matahari. Pengendalian hama dan penyakit 
biasanya dilakukan dengan penyemprotan pestisida nabati yang terbuat dari daun mimba, sereh, daun sirsak dan empon-empon. Pestisida nabati diaplikasikan setelah panen berlangsung atau satu minggu sekali pada daun dengan dosis $200 \mathrm{ml} \mathrm{ha}^{-1}$.

Kelor cenderung tumbuh secara vertikal hingga ketinggian 3-4 m. Pemangkasan awal dilakukan ketika tanaman kelor berumur tiga bulan setelah tanam dengan tinggi pangkasaan 75 $\mathrm{cm}$ dari permukaan tanah. Pemangkasan batang utama dilakukan saat tanaman sudah berumur dua tahun dengan menebang batangnya hingga memiliki ketinggian $20 \mathrm{~cm}$ dari permukaan tanah. Setelah pemangkasan batang utama, secara rutin akan dilakukan pemangkasan pemeliharaan. Pemangkasan pemeliharaan dilakukan ketika tanaman sudah memiliki tinggi lebih dari $150 \mathrm{~cm}$ atau saat tanaman sudah sulit untuk dipanen dan memiliki produktivitas yang rendah.

Kelor dipanen dengan cara memetik daun yang sudah berwarna hijau tua dan tanpa cacat pada daunnya. Daun dikumpulkan pada bak penampung hingga penuh dan dibawa untuk dilorot atau dipisahkan antara anak daun dari tangkainya. Proses pemanenan yang baik dilakukan pagi dan sore hari. Bobot daun yang sudah dilorot atau daun yang sudah dipisahkan dengan tangkainya yaitu $200 \mathrm{~kg}$ setiap kali panen. Daun yang telat dipanen ditandai dengan warna daun yang mulai menguning dan sudah tumbuh bakal daun pada ketiak daun dengan ukuran cukup besar. Kriteria daun yang dapat dipanen yaitu tangkai daun yang sudah memiliki sudut tangkai daun antara $45^{\circ}-90^{\circ}$, sudah muncul sedikit bakal daun di ketiak daunnya, daun berwarna hijau tua. Panen kelor yang baik dilakukan pagi atau sore hari.

Daun kelor masuk ke dalam ruang pengering maksimal empat jam dari waktu awal daun dipetik. Pengeringan dilakukan di dalam ruang pengeringan tertutup dengan suhu dipertahankan stabil antara $30-35{ }^{\circ} \mathrm{C}$ dan kelembaban $46 \%$ RH selama dua hari sampai benar-benar kering atau kadar air daun dibawah $5 \%$. Daun kelor kering yang baik berwarna hijau, benar-benar kering (bila diremas akan hancur atau kadar air dibawah 5\%) dan tanpa tangkai daun. Pengaturan suhu dan kelembaban merupakan kunci terpenting dalam pengeringan daun kelor.

Daun kelor kering dihaluskan dengan menggunakan mesin pembuat serbuk stainless steel. Serbuk daun kelor disaring dengan ayakan stainless steel untuk menghasilkan serbuk daun dengan tingkat kehalusan 80 mesh dan memisahkan butiran yang masih kasar. Serbuk kasar yang dihasilkan petani mitra kemudian dikirim ke PT. Agaricus Sido Makmur Sentosa (ASIMAS) untuk menghasilkan serbuk daun kelor dengan tingkat kehalusan 200 mesh dan 500 mesh. Kelor dalam bentuk serbuk dapat meningkatkan daya simpan hingga satu tahun. Kelor dalam bentuk daun kering hanya memiliki daya simpan enam bulan.

Bahan baku berupa daun kering dan serbuk kasar dari petani mitra dijual ke Kebun Organik Kelorina. Daun kering diberi harga Rp65 000.00/kg sedangkan serbuk kasar diberi harga Rp75 000.00/kg. Sistem penjualan yang diterapkan Kebun Organik Kelorina yaitu sistem terputus. Terdapat tiga jenis harga yang ditetapkan yaitu harga gerai, reseller dan eceran. Harga gerai diberikan ketika pembelian barang minimal Rp5 000000.00 dan berkomitmen membuka gerai di daerah tertentu. Harga reseller diberikan setelah pembelian produk minimal Rp2 000000.00 atau telah mengikuti pelatihan kelor. Harga eceran merupakan harga standar penjualan.

\section{Aspek Manajerial}

Karyawan harian pada Kebun Organik Kelorina terbagi menjadi beberapa divisi. Karyawan harian pada petani mitra secara umum terbagi menjadi pekerja kebun, pekerja lorot daun, pekerja pengeringan, pekerja pembuat serbuk daun kasar. Sedangkan karyawan harian pada Kebun Organik Kelorina terbagi menjadi, pekerja pembuat minyak, pekerja pembuat serbuk biji, pekerja laboratorium, pekerja pengemasan dan pekerja pengepakan. Karyawan harian mulai bekerja dari pukul 08.00-16.00 WIB dengan interval waktu istirahat selama satu jam yaitu pukul 12.00-13.00 WIB. Berdasarkan hasil evaluasi kegiatan unit kebun, manajemen sumberdaya masih kurang optimal dan masih kurangnya jumlah tenaga kerja sehingga jadwal kegiatan belum berjalan dengan baik. Hanya terdapat enam orang karyawan untuk mengerjakan seluruh tahapan budidaya tanaman. Standar jumlah tenaga kerja diperlukan untuk setiap unit produksi dan pengolahan, serta spesifikasi kerja sehingga kegiatan dapat berjalan dengan efisien dan efektif.

Kepala produksi mengemban tugas mengelola kebun untuk mencapai target produksi perusahaan, mengawasi kinerja karyawan, mengawasi kinerja unit pengering, dan bertanggung jawab langsung terhadap direktur. Perencanaan produksi yang dibuat oleh kepala produksi meliputi semua aspek terutama budidaya tanaman. Perencanaan produksi dimulai dari penanaman, pemeliharaan, hingga panen dan pascapanen. Kepala kebun menentukan bahan 
tanam yang digunakan dan waktu penanaman pada bagian penanaman. Perencanaan bagian pemeliharaan termasuk penentuan jenis, dosis, waktu pemupukan, serta jenis dan dosis pemakaian pestisida. Waktu dan jumlah yang akan dipanen ditentukan saat perencanaan panen serta perlakuan pascapanennya hingga barang dikirim ke unit pengolahan. Organisasi produksi dilakukan dengan membagi pekerja menjadi tiga unit produksi, yaitu unit kebun, unit pengeringan dan unit pembuatan serbuk kasar. Penggerakan (actuating) produksi dilakukan dengan memberikan tugas kepada setiap unit produksi sesuai perencanaan sehingga target produksi tercapai. Pengawasan (controlling) produksi juga perlu dilakukan dengan memberikan pengawasan yang intensif kepada kinerja karyawan pada setiap unit produksi sesuai standar operasional yang ditetapkan sehingga kualitas produk tetap terjaga. Berdasarkan hasil evaluasi kegiatan sebagai asisten kepala produksi, belum adanya perencanaan dan jadwal kegiatan produksi menyebabkan banyak keterlambatan kegiatan produksi sehingga tidak berjalan optimal. Perencanaan awal dan pembuatan jadwal kegiatan produksi diperlukan agar kegiatan dapat berjalan dengan teratur dan dapat dilakukan evaluasi setiap tahunnya.

Kepala pengolahan dan pemasaran mengemban tugas mengelola unit pengolahan, mengawasi kinerja karyawan, menerima pesanan dari konsumen dan menentukan jumlah produk yang diproduksi, memeriksa laporan penjualan serta bertanggung jawab langsung terhadap direktur. Perencanaan pengolahan yang dibuat oleh kepala pengolahan dan pemasaran dengan menentukan jumlah bahan baku dan produk yang dihasilkan sesuai permintaan konsumen. Organisasi pengolahan dilakukan dengan membagi pekerja menjadi pekerja pembuat minyak, pekerja pembuat serbuk, pekerja pembuat kosmetik, pekerja pengemasan dan pengepakan. Penggerakan (actuating) pengolahan dilakukan melalui koordinasi dengan karyawan terkait jumlah produksi dilakukan via telepon setiap harinya. Pengawasan (controlling) kinerja karyawan dilihat dari laporan kegiatan pekerja.

\section{Aspek Khusus}

\section{Pengaruh Perbedaan Teknik Panen terhadap Produksi}

Pengamatan teknik panen dilakukan selama tiga periode panen. Data yang didapat pada pengamatan periode panen pertama (Tabel 2) tidak dapat dianalisis karena pada periode pertama kondisi tanaman masih baru dipangkas dan daun belum siap dipanen hingga 35 hari setelah pangkas (HSP). Teknik panen petik daun periode pertama hanya memiliki satu data, yaitu data pengamatan satu kali panen. Panen petik daun diamati sebanyak lima kali panen untuk setiap periode. Panen pertama dilakukan bersamaan pada 35 HSP untuk teknik pangkas cabang dan petik daun.

Tabel 2. Data perbedaan teknik panen terhadap produksi periode 1 (35 HSP)

\begin{tabular}{lcccc} 
& \multicolumn{4}{c}{ Parameter } \\
\cline { 2 - 5 } Perlakuan & Jumlah Jumlah & $\begin{array}{c}\text { Bobot } \\
\text { brangkasan } \\
(\mathrm{g})\end{array}$ & $\begin{array}{c}\text { Bobot } \\
\text { anak }\end{array}$ \\
& cabang & daun & $\mathrm{g})$ \\
\hline $\begin{array}{l}\text { Teknik panen } \\
\text { petik daun } \\
\begin{array}{l}\text { Teknik panen } \\
\text { pangkas } \\
\text { cabang }\end{array}\end{array}$ & 6.10 & 29.60 & 150.60 & 96.40 \\
\hline
\end{tabular}

Perlakuan dibandingkan dengan melihat nilai $P$-value untuk mengetahui pengaruh perlakuan terhadap parameter yang diuji. Besarnya pengaruh perlakuan terhadap parameter dilihat dari hasil persentase perbandingan kedua teknik panen untuk setiap parameter yang diuji. Berdasarkan hasil uji perbedaan teknik panen terhadap produksi (Tabel 3), diperoleh perlakuan teknik panen tidak mempengaruhi jumlah cabang. Jumlah daun pada perlakuan teknik panen petik daun memiliki rata-rata lebih tinggi sebesar 149\% pada periode dua dan $105 \%$ pada periode tiga dari pada tanaman yang dipanen dengan teknik pangkas cabang. Tanaman yang dipanen dengan teknik pangkas cabang menggunakan banyak energinya untuk pembentukan cabang baru selama proses perkembangannya hingga tanaman tersebut dapat dipanen kembali. Sesuai dengan pernyataan Holst (2000), tanaman kelor yang dipanen dengan cara dipangkas maka semakin banyak cabang yang terbentuk sehingga semakin banyak daun yang tumbuh.

Daun kelor yang dipanen dengan teknik pangkas cabang dapat dikelompokan berdasarkan lapisannya. Lapisan atas atau pucuk merupakan daun muda dengan warna hijau muda, pada lapisan tengah merupakan daun dengan usia sedang atau medium yang memiliki warna hijau dan lapisan terbawah merupakan daun dengan usia tertua dengan warna hijau gelap. Pemanfaatan daun muda atau pucuk dari tanaman kelor digunakan untuk konsumsi sehari-hari dalam skala rumah tangga, sedangkan untuk skala industri akan sulit untuk diimplementasikan karena jumlah pucuk setiap pohon terbatas (Sugianto, 2016). Tanaman yang dipanen dengan teknik panen petik daun memiliki rata-rata bobot 
brangkasan lebih tinggi sebesar $146 \%$ pada periode kedua dan $52 \%$ pada periode ketiga dibandingkan yang dipanen dengan menggunakan teknik pangkas cabang. Bobot brangkasan pada teknik panen petik daun mengalami penurunan pada periode ketiga, sejalan dengan penurunan jumlah daun (Tabel 3). Bobot brangkasan pada perlakuan teknik pangkas cabang mengalami peningkatan walaupun sama-sama terjadi penurunan terhadap jumlah daun pada periode ketiga.

Tabel 3. Hasil uji-t perbedaan teknik panen terhadap produksi

\begin{tabular}{lrr}
\hline Perlakuan & Periode 2 & Periode 3 \\
\hline Jumlah cabang & & \\
$\begin{array}{l}\text { Teknik panen petik daun } \\
\text { Teknik panen pangkas } \\
\text { cabang }\end{array}$ & 5.10 & 4.50 \\
\hline$P$-value & 5.30 & 3.50 \\
\hline Jumlah daun & $0.87^{\text {th }}$ & $0.18^{\text {th }}$ \\
$\begin{array}{l}\text { Teknik panen petik daun } \\
\text { Teknik panen pangkas } \\
\text { cabang }\end{array}$ & 52.70 & 38.10 \\
\hline$P$-value & 21.10 & 18.50 \\
\hline
\end{tabular}

\section{Bobot brangkasan (g)}

\begin{tabular}{lcc}
$\begin{array}{l}\text { Teknik panen petik daun } \\
\text { Teknik panen pangkas } \\
\text { cabang }\end{array}$ & 549.00 & 399.00 \\
\hline$P$-value & 223.00 & 261.00 \\
\hline
\end{tabular}

\section{Bobot anak daun (g)}

\begin{tabular}{lcc}
$\begin{array}{l}\text { Teknik panen petik daun } \\
\text { Teknik panen pangkas } \\
\text { cabang }\end{array}$ & 335.40 & 238.60 \\
\hline$P$-value & 66.70 & 72.50 \\
\hline
\end{tabular}

Keterangan: : $:$ berpengaruh sangat nyata pada $\alpha=1 \%$, : berpengaruh nyata pada $\alpha=5 \%$, tn: tidak

Produksi kelor dapat dilihat dari bobot anak daunnya. Tanaman yang dipanen dengan teknik panen petik daun memiliki rata-rata bobot anak daun lebih tinggi sebesar $402 \%$ pada periode kedua dan $229 \%$ pada periode ketiga dari pada teknik panen pangkas cabang. Teknik panen petik daun pada periode ketiga mengalami penurunan $29 \%$, sedangkan dengan teknik panen pangkas cabang mengalami peningkatan sebesar $8 \%$ pada periode ketiga. Panen kelor dengan teknik panen petik daun terus mengalami penurunan produksi setelah periode panen kedua. Pemangkasan perlu dilakukan karena produktivitas tanaman rendah dan tanaman terlalu tinggi untuk dipanen. Kelor yang dipanen dengan teknik pangkas cabang menyisakan cabang, tangkai daun dan daun muda yang terbuang. Kelor yang dipanen dengan teknik petik daun yang hanya menyisakan tangkai daun. Panen kelor dengan teknik pangkas cabang lebih cocok digunakan untuk tujuan produksi pakan ternak sehingga tidak ada bagian tanaman yang terbuang dengan menggunakan jarak tanam yang lebih rapat untuk meningkatkan produksi. Kelor yang dipanen dengan teknik petik daun lebih cocok digunakan untuk tujuan produksi pangan. Sesuai dengan pernyataan Amaglo et al. (2006), jarak tanam berpengaruh signifikan terhadap pertumbuhan dan produksi kelor dengan memperhatikan pemupukan untuk produksi yang berkelanjutan. Berdasarkan penelitian Gross (2012), kepadatan tanaman yang tinggi menghasilkan biomassa tanaman yang lebih tinggi dan batang yang lebih panjang, tetapi diameter batangnya lebih kecil. Kepadatan tanaman yang lebih rendah menghasilkan biomassa tanaman yang lebih rendah, tetapi menghasilkan pertumbuhan tanaman individu yang lebih tinggi yang ditunjukkan dari hasil diameter batang yang lebih tebal. nyata.

\section{Pengaruh Pra Pengeringan terhadap Rendemen Daun Kelor Kering}

Daun basah masuk ke dalam ruang pengering secara bertahap. Rata-rata terdapat dua sesi masuknya daun ke ruang pengering yaitu pukul 11.00 dan 13.00 WIB. Daun yang lebih dahulu masuk ruang pengering mendapatkan perlakuan pra pengeringan, yaitu dengan menyalakan kipas angin dan exhaust fan pada ruang pengering. Pra pengeringan dimaksudkan untuk menjaga kelembapan ruangan dan mencegah daun terfermentasi. Pengeringan dimulai bersamaan dan periode pengeringan berlangsung 44 jam atau kurang lebih dua hari. Dua sesi masuknya daun ke pengering terjadi karena empat faktor, yaitu: adanya target daun basah yang dikeringkan yaitu $200 \mathrm{~kg}$, proses perontokkan daun dilakukan secara manual, tenaga kerja perontok daun merupakan pekerja borongan sehingga jumlah daun yang dirontokkan tidak tetap dan daun kelor masuk ruang pengering maksimal empat jam sejak daun dipanen. Perbedaan waktu masuknya daun ke ruang pengering juga menyebabkan waktu keringnya daun pada setiap rak tidak sama. Pengemasan daun kering dilakukan saat semua daun kering sempurna.

Perlakuan dibandingkan dengan melihat nilai $P$-value untuk melihat pengaruh perlakuan terhadap parameter yang diuji. Besarnya pengaruh perlakuan terhadap parameter dilihat dari hasil persentase perbandingan perlakuan pra pengeringan dan tanpa pra pengeringan untuk 
setiap parameter yang diuji. Perlakuan pra pengeringan tidak mempengaruhi kualitas daun kering dari segi jumlah air pada daun. Bobot kering dan rendemen daun tanpa pra pengeringan lebih tinggi sebesar $10 \%$ dan $13 \%$ dari daun yang dikeringkan dengan pra pengeringan (Tabel 4). Perlakuan pra pengeringan tidak harus dilakukan sehingga waktu pengeringan menjadi dua jam lebih cepat, dengan melakukan penambahan pekerja panen, pekerja perontok daun dan pekerja pengering. Perlakuan pra pengeringan dan tanpa pra pengeringan tidak mempengaruhi persentase rendemen daun kelor.

Tabel 4. Hasil uji-t perlakuan pra pengeringan terhadap rendemen daun

Parameter

\begin{tabular}{|c|c|c|}
\hline \multirow[b]{2}{*}{ Perlakuan } & \multicolumn{2}{|c|}{ 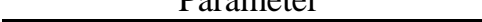 } \\
\hline & Bobot kering $(\mathrm{g})$ & Rendemen $(\%)$ \\
\hline Pra pengeringan & 457.70 & 0.22 \\
\hline $\begin{array}{l}\text { Tanpa pra } \\
\text { pengeringan }\end{array}$ & 504.30 & 0.25 \\
\hline$P$-value & $0.21^{\mathrm{tn}}$ & $0.21^{\mathrm{tn}}$ \\
\hline
\end{tabular}

Keterangan: ${ }^{* *}:$ berpengaruh sangat nyata pada $\alpha=$ $1 \%$, : : berpengaruh nyata pada $\alpha=5 \%$, tn: tidak nyata.

\section{KESIMPULAN}

Panen kelor dengan teknik pangkas cabang lebih cocok digunakan untuk tujuan produksi pakan. Adapun kelor yang dipanen dengan teknik petik daun lebih cocok digunakan untuk tujuan produksi pangan. Baik perlakuan pra pengeringan dan tanpa pra pengeringan tidak mempengaruhi rendemen daun kelor kering.

\section{DAFTAR PUSTAKA}

Amaglo, N.K., G.M. Timpo, W.O. Ellis, R.N. Bennett. 2006. Effect of spacing and harvest frequency on the growth and leaf yield of moringa (Moringa oleifera Lam.), a leafy vegetable crop. Moringa and other highly nutritious plant resources: Strategies, standards and markets for a better impact on nutrition in Africa. International workshop on Moringa. Accra, 16-18 November 2006.

Aminah, S., T. Ramdhan, M. Yanis. 2015. Kandungan nutrisi dan sifat fungsional tanaman kelor (Moringa oleifera). Buletin Pertanian Perkotaan 5(2):35-44.

Desiawati, D. 2013. Tinjauan konservasi kelor (Moringa oleifera Lam.): studi kasus di Desa Cikarawang Kecamatan Dramaga
Kabupaten Bogor. [Skripsi]. Institut Pertanian Bogor, Bogor.

Gross, M. 2012. A study of the initial establishment of multi-purpose moringa (Moringa oleifera Lam) at various plant densities, their effect on biomass accumulation and leaf yield when grown as vegetable. Afr. J. Plant Sci. 6(3):125129.

Holst, S. 2000. Moringa: Nature's Medicine Cabinet. Sierra Sunrise Publishing, California.

Joshi, P., D. Mehta. 2010. Effect of dehydration on the nutritive value of moringa leaves. J. Metabolomics Syst. Biol. 1(1):5-9.

Krisnadi, A.D. 2015. Kelor Super Nutrisi. Morindo Moringa Indonesia, Blora.

Martha, D.A.B., E. Prihastanti, S. Haryanti. 2016. Perbedaan kadar glukosa, karotenoid dan biomassa alang-alang (Imperata cylindrica L. Beauv) yang tumbuh di daerah ternaungi di Kecamatan Kunduran Blora dan Ungaran Timur, Semarang. Buletin Anatomi dan Fisiologi 1(1):59-67.

Mishra, S.P., P. Singh, S. Singh. 2012. Processing of Moringa oleifera leaves for human consumption. Bull. Env. Pharmacol. Life Sci. 2(1):28-31.

Mitariastini, N.L.G. 2016. Pertumbuhan dan produksi beberapa aksesi kelor (Moringa oleifera Lam.) pada interval pemanenan berbeda. [Skripsi]. Institut Pertanian Bogor, Bogor.

[Moringa Indonesia]. 2014. Kebun Kelor Organik. http://moringa.co.id/kebunkelor-organik/ [11 Maret 2017].

Sugianto, A.K. 2016. Kandungan gizi daun kelor (Moringa oleifera) berdasarkan posisi daun dan suhu penyeduhan. [Skripsi]. Institut Pertanian Bogor, Bogor.

Sohaimy, S.A.E., G.M. Hamad, S.E. Mohamed, M.H. Amar, R.R.A. Hindi. 2015. Biochemical and functional properties of Moringa oleifera leaves and their potential as a functional food. Glo. Adv. Res. J. Agric. Sci. 4(4):188-199.

Sutarjo, U.S., D. Budijanto. 2017. Profil Kesehatan Indonesia Tahun 2016. Kementerian Kesehatan Republik Indonesia, Jakarta. 